\title{
ECONOMICAL DICHOTOMOUS SEARCH FOR MINIMIZING ONE-VARIABLE FUNCTIONS
}

\author{
Kodnyanko V. A. - Dr. Sc., Professor, Polytechnic Institute, Siberian Federal University, Krasnoyarsk, Russia.
}

\begin{abstract}
Context. The hypothesis about computational redundancy of the dichotomy method used for conditional minimization of unimodal functions was formulated, and on this basis the idea of the possibility creating a more efficient method was suggested.

Objective. The aim of the work is to develop a technique for eliminating computational redundancy of the dichotomy method and the creation numerical method of increased speed called the economical dichotomy method. The algorithm and program code implementing the method are also subjected to development.

Method. The method is based on the unimodality property of the function being minimized, which, under certain conditions, allows to reduce the number of calculations of the function being optimized, which helps to increase the speed of the economical search.

Results. The given results of the computational experiment showed that, according to speed, determined by the number of calculations of the minimized function, the economical method is not less than 1.5 times more efficient than the classical dichotomous search. This means that, on average, of the three calculations of the minimized function using the dichotomy method, one is redundant. Compared with the golden section search, which is the fastest method of the cut-off family, and the dichotomous search, in the average statistical terms, the economical method has approximately 1.3 and 1.7 times faster response, respectively. That is, the economical method works so many times faster than the golden section search, how many times the latter works faster than the classical dichotomous search.

Conclusions. These findings make it possible to take a critical look at the well-established notion that the dichotomous search is the worst of the series methods for cutting off segments. Taking into account the obtained results, the economical method of dichotomy is noticeably superior in speed to the best of them - the golden section search and can reasonably claim to be a leader in this series of methods.
\end{abstract}

KEYWORDS: unimodal function, dichotomous search, golden section search, economical dichotomous search, monotone function, method speed.

\begin{abstract}
ABBREVIATIONS
GSS - golden section search;

DS - dichotomous search;

EDS - economical dichotomous search;

$\mathrm{MF}$ - minimized function.
\end{abstract}

\section{NOMENCLATURE}

$\varepsilon, e$-accuracy of method;

$f(x)$ - minimized function;

$G=[a, b]-$ uncertainty interval;

$a, b, \mathrm{a}, \beta$-parameters of uncertainty interval;

$x$ - abscissa of the minimum of function $f(x)$;

$x_{1}, x_{2}, x_{3}, x_{4}$ - points of dichotomy;

$h$ - ratio of divide;

$u_{i}$ - current extreme point of the interval;

$i$ - number of current extreme point;

$p(i)=x+i e$ calculating dichotomy point;

$k_{1}, k_{2}, k, K_{1}, K_{2}$ - speed of methods;

Eds, $M d, Y, M g$ - algorithm names.

\section{INTRODUCTION}

Minimizing the function of one variable is the simplest type of optimization problem. However, it occupies an important place in the development and practical application of mathematical methods for their solution, including numerical methods [1-5]. This is due to the fact that only with the help of numerical methods many engineering and economic tasks can be solved, not only with one-parameter optimization, but also with more complex multiparameter problems.
Unimodal functions are subjected to conditional minimization procedures in the practice of onedimensional optimization.

There are various definitions of functions of this class, therefore we will adhere to the definition [2-3, 6-10,14], according to which the unimodal is called the function $f$ (x) defined on the interval $[a, b]$ if the numbers $\alpha$ and $\beta$ exist, and

$$
a \leq \alpha \leq \beta \leq \mathrm{b} \text {, such as: }
$$

1) if $a<\alpha$, then the function $f(x)$ monotonically decreases on the interval $[a, \alpha]$;

2 ) if $\beta<b$, then the function $\mathrm{f}(\mathrm{x})$ monotonically increases on the segment $[\beta, b]$;

3 ) on the interval $[a, \beta]$, the function $f(x)$ is constant and reaches its minimum.

The main requirements that apply to numerical methods of one-dimensional minimization are their reliability and acceptable performance. It is believed that the smaller the calculation of the minimized function is required for the method to achieve the result, the more effective it is and the higher its speed.

\section{PROBLEM STATEMENT}

The method of economical dichotomous search is designed to find the abscissa $x$ of the minimum of the unimodal function $f(x)$ on the interval $G=[a, b]$ with an accuracy of $\varepsilon$. 


\section{REVIEW OF THE LITERATURE}

Three methods for eliminating segments are known: the golden section search, the Fibonacci number method and the dichotomous search, corresponding these requirements $[4-6,8,12-17,22]$. The first two methods have approximately the same speed, so in practice they usually use GSS, which is characterized by simplicity. It is believed that the DS has a significantly lower speed, so it almost does not find practical application.

The reason for the reduced speed of the DS is that, although the method narrows the uncertainty segment about twice for one iteration, and the GSS is only about 1.62 times, the first requires two calculations of the MF, while the second, not counting the first iteration, requires only one of its calculations. As a result, GSS has a higher speed.

In the scientific literature there are no clearly expressed conclusions about the unpromising DS, because it is assumed that it can be improved. In this sense, the following general wish of specialists is characteristic: "A more thoughtful approach to the process of finding the minimum point allowed saving on the number of calls to the function calculation. However, in the method of dichotomy there is a feature that allows you to build more efficient algorithms. At each iteration, it is necessary to calculate the value of the function at two new points. If we succeed in constructing an algorithm so that each time one of these points coincides with one of the similar points from the previous iteration, it would allow at each iteration to calculate the value of the function only at one new point and thereby turn to even less function calculation" [7, 9, 17-18, 23].

Similar points of view prevail in many works on numerical minimization methods, including fundamental publications of well-known and authoritative specialists, including world-famous scientists [1-10]. However, attempts to improve DS to a competitive level based on the implementation of the expressed idea or otherwise (for example, $[11,19,21,23])$ have so far failed.

The dichotomy method is computationally redundant in the sense that there is at least a theoretical possibility of reducing the number of calls to the MF to solve the above problems with the required accuracy.

The purpose of this article is to study the possibility of increasing the speed of DS to a competitive level by eliminating its computational redundancy. The method in which redundant calculations of MF are excluded is given the name of the economical dichotomous search.

\section{MATERIALS AND METHODS}

The method is based on DS. Its essence is as follows. The method is based on DS $[2,12,14,20]$. Its essence is as follows. Let on the current iteration of the DS the abscissas of the dichotomy $x_{1}=x-\varepsilon, x_{2}=x+\varepsilon$ and the corresponding values of the function $f\left(x_{1}\right)$ and $f\left(x_{2}\right)$ are calculated and let $f\left(x_{1}\right) \geq f\left(x_{2}\right)$, as shown in Fig. 1 .

In this case, the DS would require at the next iteration the computation of the MF at similar points $x_{3}$ and $x_{4}$.

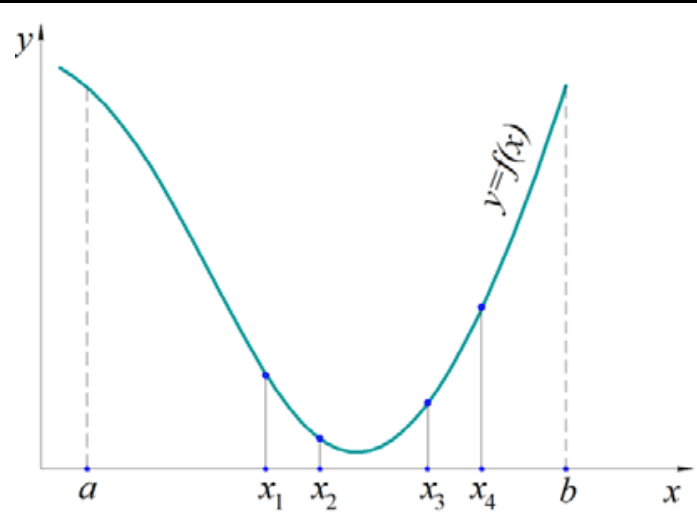

Figure 1 - Calculation scheme of EDS

However, before we calculate the MF at the point $x_{3}$ closest to $x_{2}$. If $f\left(x_{3}\right)<f\left(x_{2}\right)$, as shown in Fig. 1, the calculation of $f\left(x_{4}\right)$ is redundant, because, based on the unimodality property of the MF, it is possible without the calculation of $f\left(x_{4}\right)$ to establish that $f\left(x_{3}\right) \leq f\left(x_{4}\right)$, and immediately reduce the uncertainty interval by changing the abscissa $b$ and completing iteration. This circumstance indicates the possibility of reducing the number of calculations of the MF.

The reasoning is similar for the mirror situation, when $f\left(x_{1}\right) \leq f\left(x_{2}\right)$.

In order to confirm the stated idea and to evaluate the practical availability of the EDS, algorithms and program code in the Delphi language were developed.

The block diagram of the Eds algorithm that implements the method is shown in Fig. 2

The input parameters of the algorithm are: $a, b-$ the left and right borders of the $G$ segment, respectively, $e$ is accuracy of determining the abscissa of extremum, $h$ is the coefficient used to divide the current uncertainty segment in a given ratio, $f$ is the name of the MF. Output parameters: $x$ is the abscissa of the minimum of the MF, $n$ is the counter of the number of calculations of the MF, which determines the speed of the method.

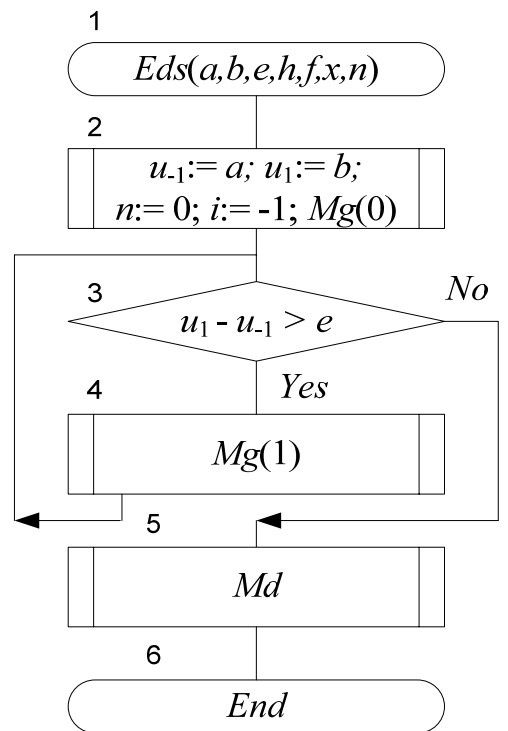

Figure 2 - Block diagram of the Eds algorithm 
The Eds algorithm uses internal auxiliary algorithms (not shown in Fig. 2):

1) $M d$ - abscissa calculations $x=u_{i}+h\left(u_{-i}-u_{i}\right)$ dividing the uncertainty segment in a given relation, where $i$ is the index of the direction of the iteration $(i=-1$ is the movement to the left boundary of the segment, $i=1$ to its right boundary),

2) $M g$ - perform actions on the current iteration (Fig. $3)$. During the initialization of the computational process in block 2 of the Med algorithm, the elements of the array $u$ are assigned the values of the corresponding boundaries of the segment $G$, the counter $n$ is reset and the direction $i$ is set. Then, using the $M g$ algorithm, the first iteration of the Med algorithm is performed.

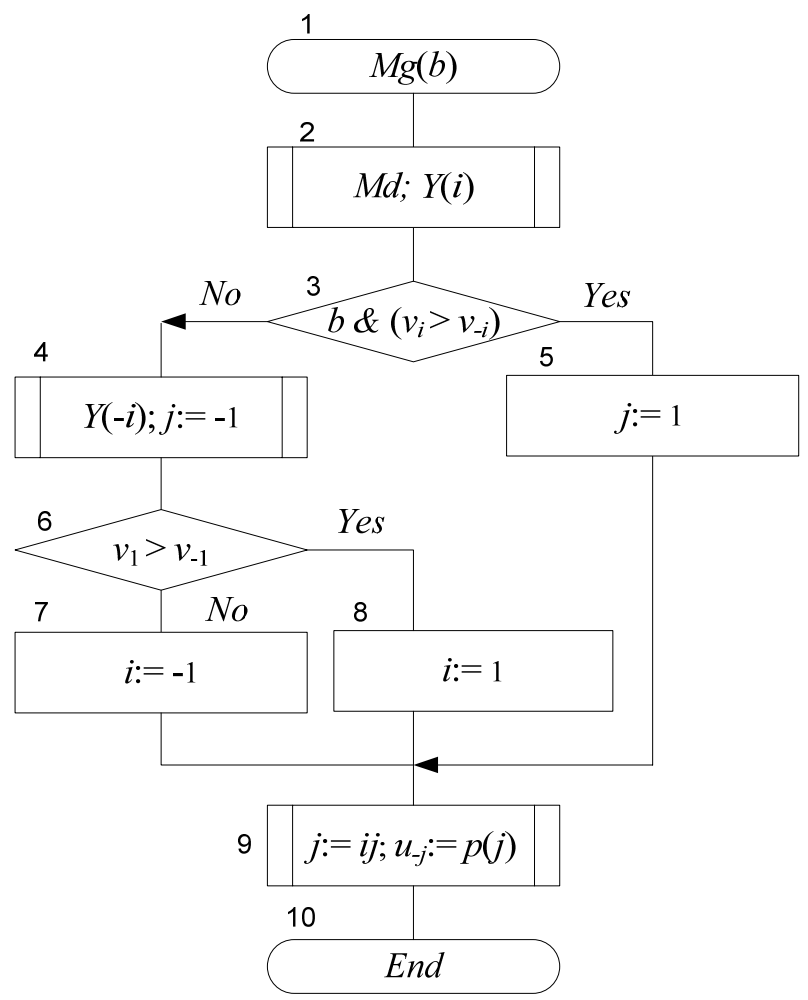

Figure 3 - Block diagram of the $M g$ algorithm

Blocks 3 and 4 form a loop of iterations implemented by the $M g$ algorithm. In block 5, the found solution $x$ is refined by referring to the $M d$ algorithm.

The block diagram of the auxiliary $M g$ algorithm is shown in Fig. 3. It uses internal algorithms (not shown in Fig. 3):

1) calculating $p(i)=x+i e$ the abscissa of the dichotomy point,

2) $Y$ - computations of the ordinate $v_{i}=f(p(i))$ of the point of dichotomy and update $n$.

The $M g$ algorithm contains the input parameter $b$ of the logical type. With a false value of the parameter (0), the first iteration of the Med algorithm is performed using the dichotomy method, and with the true value (1), subsequent iterations with the control of calculations using the economical dichotomous search.

(C) Kodnyanko V. A., 2019

DOI 10.15588/1607-3274-2019-3-4
As a result of these improvements, the new method should speed up the procedure for solving the problem of finding a minimum of MF.

\section{EXPERIMENTS}

To assess the efficiency and effectiveness of the EDS, a comparative computational experiment was conducted using examples of solving dozens of optimization problems for unimodal functions of various types: smooth, gentle, slowly changing, piecewise, monotonic.

The calculations were carried out for $\varepsilon=10^{-5}$ using variables and constants of arithmetic type supporting 1920 significant digits. 11].

The GSS and DS were used as control methods [3-

An example of one of the experimental functions is shown in Fig. 4. The function has a minimum at the point $x=1.24955$

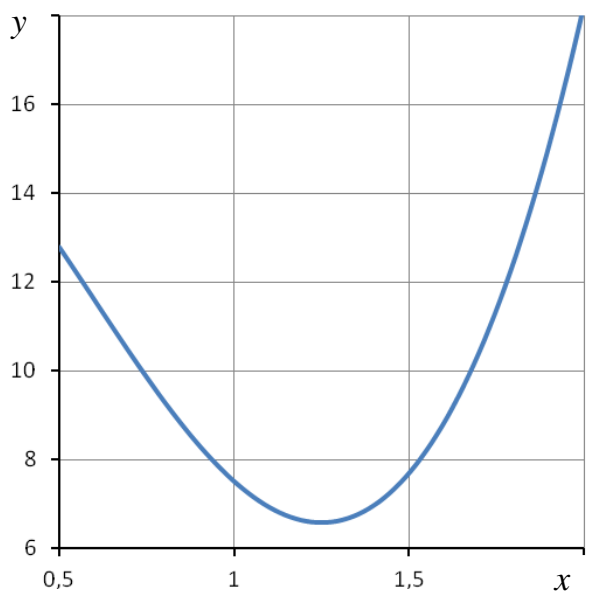

Figure 4 - Graph of the function

$$
f(x)=15 \exp \left(-x^{2}\right)+2\left(x^{2}-x+1\right)^{2}
$$

The criteria for evaluating the speed of the methods were taken as the number of calculations of the MF: $k-$ by EDS, $k_{1}$ - by GSS, $k_{2}$ - by DS. We studied the relative values of $K_{1}=k_{1} / k$ and $K_{2}=k_{2} / k$ - the speed of the GSS and DS reduced to the EDS, respectively.

As a result of the experiments, it was established that the boundaries of the segment $G$ have a significant effect on the speed of the method under study. At the same time, depending on the values of the $h$ parameter, the EDS in comparison with the GSS showed both the best and the worst results.

To get an answer to the question, which of these two methods is more effective, a statistical calculation was carried out. At the same time, the effectiveness of EDS in relation to DS was studied. To do this, for a fixed value of $h$, two sufficiently wide intervals were taken - to the left and right of the extremum point, then, randomly, combinations of the values of boundaries $a$ and $b$ were selected from them and calculations were performed for $\mathrm{m}$ combinations of the values of these parameters. For MF, presented in Fig. 4, intervals were selected $[0.0 ; 1.1]$ for a and $[1.3 ; 2.5]$ for $b$, the number of experiments $m=500$. 
Graphs of the characteristics of $K_{1}$ and $K_{2}$ on the parameter $h$ for this experiment are presented in Fig. 5.

It is seen that the dependencies are extreme. At the same time, their highest values fall on the range $h \in$ $[0.25 ; 0.40]$. The highest values of these characteristics are $K_{1}=1.31$ and $K_{2}=1.70$, that is, at optimal values of $h$, the EDS in speed is on average much more than GSS and DS, respectively.

Calculations showed that at $h=0.5$, which corresponds to the half-division method, in 476 (95\%) experiments, the EDS showed the same or best results with the GSS, and the best results in $430(86 \%)$ experiments. However, already at $h=0.4$, similar indicators improved significantly and amounted to 498 (99\%) and 496 (99\%) MF calculations, respectively.

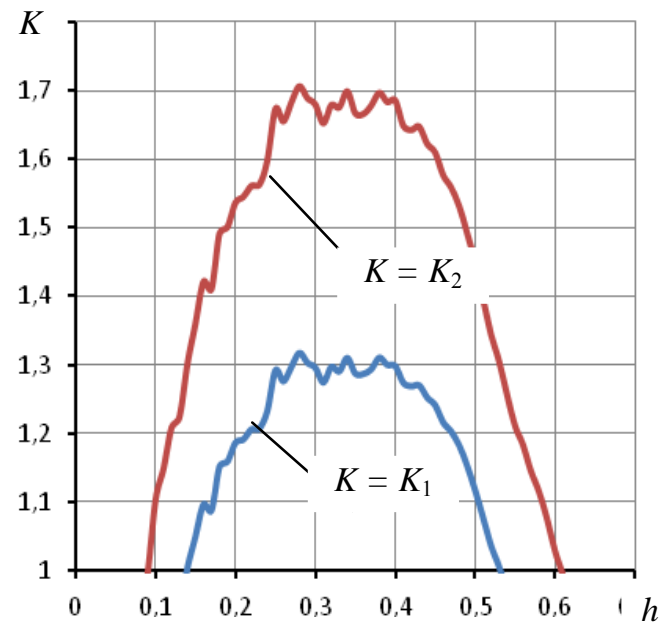

Figure 5 - Graphs of relative performance of methods

In absolute terms, this means that if GSS and DS to calculate the extremum, on average, requires $k_{1}=28$ and $k_{2}=36$ calculations of MF, respectively, then the EDS finds an average solution for $k=21$ of its calculations.

\section{RESULTS}

Experiments have shown that the EDS has a reduced response rate while minimizing monotonic functions. However, this type of function is not typical for optimization problems, and, therefore, this fact is not fatal. However, this disadvantage of the method can be overcome by a simple algorithm upgrade. If, with several consecutive calculations of the MF, there is a tendency towards monotony of the current results, then it is sufficient to calculate the MF at the extreme point of the uncertainty interval and at the point separated from it by $\varepsilon$, and if it turns out that these points also fit into the monotonicity forecast, then the function is indeed monotonic.

\section{DISCUSSION}

Thus, the hypothesis about the computational redundancy of the classical dichotomy method used to

(C) Kodnyanko V. A., 2019

DOI 10.15588/1607-3274-2019-3-4 minimize unimodal functions expressed in the paper has found its theoretical and experimental substantiation.

It has been established that the EDS works at least 1.5 times faster than its classic forerunner. This means that, on average, out of three calculations of the MF by DS, at least one is redundant.

The method is quite sensitive to the parameters of the segment of uncertainty and with respect to the GSS it can work both faster and slower than it, however, with $\mathrm{h} h \in$ [0.25; 0.40] EDS usually requires fewer MF calculations to achieve a result.

The general conclusion is that, while minimizing the extremes on the interval of uncertainty of the MF compared to the GSS and the DS, in the average statistical level, the EDS will have approximately 1.3 and 1.7 times faster response, respectively. In other words, when solving such problems the EDS works many times faster than GSS, when GSS works faster than classic DS.

\section{CONCLUSIONS}

This conclusion makes it possible to take a critical look at the well-established notion that the dichotomy method is the worst of the cut-off methods. Taking into account the obtained results, the economical method of dichotomy is noticeably superior in speed to the best of them - the golden section method and can reasonably claim to be a leader in this family of methods.

Thus, having certain advantages over the golden section search, the economical dichotomous search seems preferable in practical use.

\section{ACKNOWLEDGEMENTS}

The work was carried out within the framework of the scientific research budget themes «Methods of modeling and optimizing of quality control information systems on the basis of intellectual technologies») at the Department of Standardization, Metrology and Quality Management of the Polytechnic Institute of the Siberian Federal University.

\section{REFERENCES}

1. Kiefer J. K. Sequential minimax search for a maximum, Proceedings of the American Mathematical Society, 1953, Vol. 4, No. 3, pp. 502-506.

2. Rao S. S. Engineering optimization: theory and practice. 4 th ed. Hoboken (New Jersey), John Wiley \& Sons, 2009, $320 \mathrm{p}$.

3. Wilde D. J. Optimum Seeking Methods. New Jersey, Prentice Hall, 1964, 196 p.

4. Panteleev A. V., Letova T. A.. Metody optimizacii v primerah i zadachah. Moscow, Vysshaya shkola, 2005, $544 \mathrm{p}$.

5. Attetkov A. V., Galkin S. V., Zarubin B. C. Metody optimizacii, 2-e izd. stereotip. Moscow, MGTU im. N. E. Baumana, 2003, 139 p.

6. Izmajlov A. F., Solodov M. V. CHislennye metody optimizacii. Moscow, Fizmatlit, 2005, 156 p.

7. Abbasov M. E. Metody optimizacii. Sankt-Peterburg, VVM, 2014, 263 p.

8. Pshenichnyj B. N., Danilin YU. M. CHislennye metody v ekstremal'nyh zadachah. Moscow, Nauka, 1975, 278 p. 
9. Moiseev N. N., Ivanilov YU. P., Stolyarova E. M. Metody optimizacii. Moscow, Nauka, 1978, 245 p.

10. Aoki M. Introduction to optimization techniques: Fundamentals and Applications of Nonlinear Programming. London, Macmillan, 1971, 335 p.

11. ZHadan V. G. Metody optimizacii. Moscow, MFTI, 2015, CH. 2: CHislennye algoritmy, $320 \mathrm{p}$.

12. Hassin R., Reuven H. Asymptotic analysis of dichotomous search with search and travel costs, European Journal of Operational Research, 1992, Vol. 58(1), pp. 78-89.

13. Fletcher R. Practical Methods of Optimization, 2nd ed. Chichester, Wiley, 1987, pp. 78-89.

14. Gill P. E., Murray W., Wright M. H. Practical Optimization. London, Academic Press, 1981, 509 p.

15. Himmelblau, D. M. Applied Nonlinear Programming. New York, McGraw-Hill, 1972, $310 \mathrm{p}$.

16. Suharev A. G., Timohov A. V., Fedorov V. V. Kurs metodov optimizacii : ucheb. posobie, 2-e izd. Moscow, Fizmatlit, 2005. $-368 \mathrm{p}$.
17. Gottfried B. S., Weisman J. Weisman, Introduction to Optimization Theory. New Jersey, Prentice-Hall, 1973, $372 \mathrm{p}$.

18. Adbyand P. R., Dempster M. A. H.. Introduction to Optimization Methods. London, Chapman and Hall, 1974, $423 \mathrm{p}$.

19. Beightler C. S., Phillips D. T., Wilde D. J. Foundations of Optimization. New Jersey, Prentice-Hall, 1979, 584 p.

20. Bazaraa M. S., Shetty C. M. Nonlinear Programming, Theory and Algorithms. New York, Wiley, 1979, 406 p.

21. Vasil'ev, F. P. Metody optimizacii. Moscow, Faktorial Press, 2002, $824 \mathrm{p}$.

22. Evtushenko YU. G. Metody resheniya ekstremal'nyh zadach $\mathrm{i}$ ih primenenie $\mathrm{v}$ sistemah optimizacii. Moscow, Nauka, 1982, $521 \mathrm{p}$

23. Box M. J., Davies D., Swann W. H. Nonlinear Optimization Techniques. London, Oliver and Boyd, 1969, 416 p.

Received 27.03.2019.

Accepted 03.06.2019.

УДК: 519.67

\section{МІНІМІЗАЦІЯ ФУНКЦІЙ ОДНІСЇ ЗМІННОЮ МЕТОДОМ ЕКОНОМНОЇ ДИХОТОМІї}

Коднянко В. А. - д-р техн. наук, професор, Політехнічний інститут, Сибірський федеральний університет, Красноярськ, Росія.

\section{АНОТАЦІ}

Актуальність. Висунута ідея усунення обчислювальної надмірності методу дихотомії, використовуваного для умовної мінімізації унімодальних функцій, та на ії основі сформульовано похід до створення більш ефективного методу оптимізації функцій однієї змінної.

Метою даної роботи є розробка методики усунення обчислювальної надмірності методу дихотомії і створення чисельного методу підвищеної швидкодії, названого методом економної дихотомії. Розробці підлягають алгоритм і програмний код, що реалізують метод.

Метод. В основі методу лежить властивість унімодальне мінімізується, яке за певних умов дозволяє скоротити кількість обчислень оптимізується функції, що дозволяє підвищити швидкість економічного пошуку методом дихотомії.

Результати. Наведені результати обчислювального експерименту показали, що за швидкодією, що визначається кількістю обчислень функції, що мінімізується, економічний метод не менш ніж в 1,5 рази ефективніше класичного методу дихотомії. Це означає, що в середньому з трьох обчислень мінімізованої функції з використанням методу дихотомії один $\epsilon$ надмірною. У порівнянні $з$ пошуком по методу золотого перетину, який $є$ найшвидшим методом в сімействі методів відсікання відрізків, і методом дихотомії в середньостатистичному щодо економний метод дає приблизно в 1,3 і 1,7 рази швидший пошук, відповідно.

Висновки. Отримані результати дозволяють висновок про те, що запропонований економний метод дихотомії може обгрунтовано претендувати на лідерство в сімействі методів відділення відрізків.

КЛЮЧОВІ СЛОВА: унімодальне функція, метод дихотомії, метод золотого перерізу, метод економною дихотомії, монотонна функція, швидкодія методу.

УДК: 519.67

МИНИМИЗАЦИЯ ФУНКЦИЙ ОДНОЙ ПЕРЕМЕННОЙ МЕТОДОМ ЭКОНОМНОЙ ДИХОТОМИИ

Коднянко В. А. - д-р техн. наук, профессор, Политехнический институт, Сибирский федеральный университет, Красноярск, Россия.

\section{АННОТАЦИЯ}

Актуальность. Выдвинута идея устранения вычислительной избыточности метода дихотомии, используемого для условной минимизации унимодальных функций, и на ее основе сформулирован поход к созданию более эффективного метода оптимизации функций одной переменной.

Целью данной работы является разработка методики устранения вычислительной избыточности метода дихотомии и создания численного метода повышенного быстродействия, названного методом экономной дихотомии. Разработке подлежат алгоритм и программный код, реализующие метод.

Метод. В основе метода лежит свойство унимодальности минимизируемой функции, которое при определенных условиях позволяет сократить количество вычислений оптимизируемой функции, что позволяет повысить скорость экономичного поиска методом дихотомии.

Результаты. Приведенные результаты вычислительного эксперимента показали, что по быстродействию, определяемому количеством вычислений минимизируемой функции, экономичный метод не менее чем в 1,5 раза эффективнее классического метода дихотомии. Это означает, что в среднем из трех вычислений минимизированной 
функции с использованием метода дихотомии один является избыточным. По сравнению с поиском по методу золотого сечения, который является самым быстрым методом в семействе методов отсечения отрезков, и методом дихотомии в среднестатистическом отношении экономный метод дает примерно в 1,3 и 1,7 раза более быстрый поиск, соответственно.

Выводы. Полученные результаты позволяют вывод о том, что предложенный экономный метод дихотомии может обоснованно претендовать на лидерство в семействе методов отделения отрезков.

КЛЮЧЕВЫЕ СЛОВА: унимодальная функция, метод дихотомии, метод золотого сечения, метод экономной дихотомии, монотонная функция, быстродействие метода.

\section{ЛІТЕРАТУРА / ЛИТЕРАТУРА}

1. Kiefer J. K. Sequential minimax search for a maximum / J. K. Kiefer // Proceedings of the American Mathematical Society. - 1953. - Vol. 4, No. 3. - P. 502-506.

2. Rao S. S. Engineering optimization: theory and practice. / S. S. Rao. -4 th ed. - Hoboken (New Jersey) : John Wiley \& Sons, 2009. $-320 \mathrm{p}$.

3. Wilde D. J. Optimum Seeking Methods / D. J. Wilde. - New Jersey : Prentice Hall, 1964. - 196 p.

4. Пантелеев А. В. Методы оптимизации в примерах и задачах / А. В. Пантелеев, Т. А. Летова. - М. : Высшая школа, 2005. - 544 с.

5. Аттетков А. В. Методы оптимизации / А. В. Аттетков, С. В. Галкин, В. С. Зарубин. - 2-е изд. стереотип. - М. : МГТУ им. Н. Э. Баумана, 2003. - 139 с.

6. Измайлов А. Ф. Численные методы оптимизации / А. Ф. Измайлов, М. В. Солодов. - М. : Физматлит, 2005. - 156 c.

7. Аббасов М. Э. Методы оптимизации / М. Э. Аббасов. СПб. : ВВМ, 2014. - 263 c.

8. Пшеничный Б. Н. Численные методы в экстремальных задачах / Б. Н. Пшеничный, Ю. М. Данилин. - М. : Наука, 1975. - 278 с.

9. Моисеев Н. Н. Методы оптимизации / Н. Н. Моисеев, Ю. П. Иванилов, Е. М. Столярова. - М. : Наука, 1978. $245 \mathrm{c}$.

10. Aoki M. Introduction to optimization techniques: Fundamentals and Applications of Nonlinear Programming / M. Aoki. - London : Macmillan, 1971. - 335 p.

11. Жадан, В. Г. Методы оптимизации. / В. Г. Жадан. - М. : МФТИ, 2015. - Ч. 2: Численные алгоритмы. -320 с.

12. Hassin R. Asymptotic analysis of dichotomous search with search and travel costs / R. Hassin, H. Reuven // European
Journal of Operational Research. - 1992. - Vol. 58(1). P. 78-89.

13. Fletcher R. Practical Methods of Optimization / R. Fletcher. - 2 nd ed. - Chichester : Wiley, 1987. - P. 7889.

14. Gill P. E. Practical Optimization / P. E. Gill, W. Murray, M. H. Wright. - London : Academic Press, 1981. - 509 p.

15. Himmelblau D. M. Applied Nonlinear Programming / D. M. Himmelblau. - New York : McGraw-Hill, 1972. $310 \mathrm{p}$.

16. Сухарев А. Г. Курс методов оптимизации : учеб. пособие / А. Г. Сухарев, А. В. Тимохов, В. В. Федоров. 2-е изд. - М. : Физматлит, 2005. - 368 с.

17. Gottfried B. S. Weisman,Introduction to Optimization Theory / B. S. Gottfried, J. Weisman. - New Jersey : Prentice-Hall, 1973. -372 p.

18. Adbyand P. R. Introduction to Optimization Methods / P. R. Adbyand, M. A. H. Dempster. - London : Chapman and Hall, 1974. -423 p.

19. Beightler C. S. Foundations of Optimization / C. S. Beightler, D. T. Phillips, D. J. Wilde. - New Jersey : Prentice-Hall, 1979. - 584 p.

20. Bazaraa M. S. Nonlinear Programming, Theory and Algorithms / M. S. Bazaraa, C. M. Shetty. - New York : Wiley, 1979. - 406 p.

21. Васильев Ф. П. Методы оптимизации / Ф. П. Васильев. М. : Факториал Пресс, 2002. - 824 с.

22. Евтушенко Ю. Г. Методы решения экстремальных задач и их применение в системах оптимизации / Ю. Г. Евтушенко. - М. : Наука, 1982. - 521 с.

23. Box M. J. Nonlinear Optimization Techniques / M. J. Box, D. Davies, W. H. Swann. - London : Oliver and Boyd, 1969. $-416 \mathrm{p}$. 